\section{Taking money from the devil in Victoria}

Just over a vear ago the Australian state of Victoria introduced the sort of antismoking legislation that is becoming commonplace elsewhere: out went cigarette advertising on billboards and in the cinema, the production and sale of smokeless tobacco, and lenient laws prohibiting the sale of tobacco to minors.

The Victorian Tobacco Bill differed, however, by introducing a "tobacco tax" of 11 cents on each packet of cigarettes. In 1988 the levy yielded about $\$ A 23 \mathrm{~m}$ (or $£ 10 \mathrm{~m}-£ 2.50$ per head of population), paid directly by the treasury to the Victorian Health Promotion Foundation, set up by the bill and staffed by government appointees.

The foundation is an extremely creative alternative to such fiascos as Britain's Health Promotion Research Trust. Its objectives are both popular and sensible in public health terms. They include the promotion of health and safety, the prevention and early detection of disease, and research relevant to these objectives. A third of the money must be allocated to sporting bodies and a similar amount to health promotion programmes. Of the remainder, one quarter will go to formal medical research and the remainder is available for commitment to any of the stated objectives.

The foundation's policy has been to buy back cultural and sporting events sponsored by the tobacco industry, and already this has happened in opera, Australian Rules football, soccer, horse racing, dog racing, and motor racing. (The total contributions to sporting bodies, including those not previously in receipt of tobacco money, are expected to be between three and four times as much as those made by the tobacco industry.) The bill did not prohibit tobacco company sponsorship of sport, although bodies that accept such sponsorship will not be eligible for other support. One of Victoria's horse racing clubs, which recently accepted sponsorship worth \$A 200000 from the manufacturer of a brand with a large slice of the adolescent market, is now having trouble attracting the expected government support for its rebuilding programme.

The campaign was led by a group of public health bodies that included the Anti-Cancer Council of Victoria, the National Heart Foundation, and many others. An organised lobby led to a mass letter writing campaign by members of the scientific establishment, many of whom telephoned their members of parliament; so did a useful percentage of the Anti-Cancer Council's 150000 charitable donors. The conservative medical establishment, the conservative business establishment, and the churches made their views clear to both parliamentary parties.

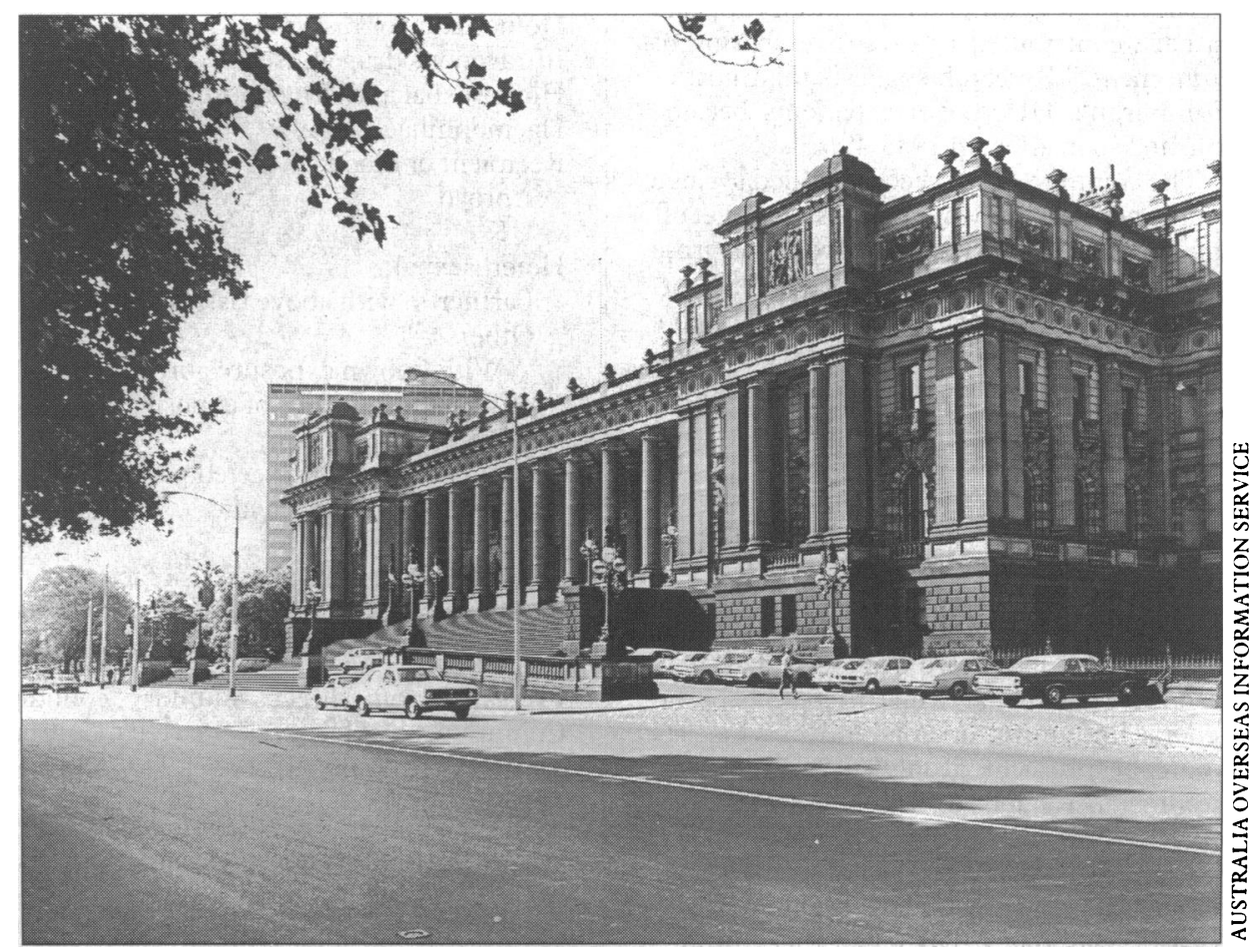

Parliament House, Melbourme

An opinion poll during the campaign showed that four out of five Victorians either approved of the antismoking campaign or thought it should be tougher. (Only 37\% approved an outright ban on sporting sponsorship by tobacco companies, although this increased to $57 \%$ if replacement sponsorship was provided.)

The bill passed through both Houses of Parliament with the unanimous support of all parties: a rare event in Australian politics and evidence that interest in public health does not follow party lines.

For many years antismoking campaigners have had to concentrate on prohibitions against advertising and other forms of promotion and sales to children. This new legislation introduces a positive element: a popular tax. Its proceeds allow the promotion of health and sport and provide the funds to redeem those sporting heroes and other role models from what must have seemed, to impressionable minds, their endorsement of smoking. - NIGEL GRAY, director, Anti-Cancer Council of Victoria

\section{Scottish AIDS}

Last year in Scotland 36 new cases of AIDS were diagnosed and 14 people died from the disease - a small contribution to the cumulative total of 1982 cases and 1059 deaths from AIDS in the United Kingdom. Doctors following up a cohort of drug abusers in Edinburgh have warned against any complacency, however: more than half of those positive for HIV have the haematological abnormalities that suggest they will develop AIDS in the next year or two.

By the end of last year 1578 people $-55 \%$ of them intravenous drug abusers-were positive for HIV in Scotland. Concentrated in Edinburgh, the drug abusers give the city a prevalence of HIV antibody comparable with that of New York and Milan. The Lothian Health Board now has the highest known prevalence of HIV antibody of any health board or region in Britain: it recently estimated that $1 \%$ of all Edinburgh males aged 15-44 are infected with the virus.

In surveys of people injecting drugs who did not use syringe exchange schemes the Monitoring Research Group found that three quarters of those in Scotland had shared syringes in the previous four weeks compared with half in England.

Scotland's problems are now being exported. Many of Scotland's infected drug abusers leave for good-some to avoid the stigmatisation of being both drug abusers and HIV positive, others to obtain easier access to drugs or services. In drug dependency units in several English cities Scottish drug abusers infected before they left Scotland now make up the largest group of HIV positive subjects. Workers in drug prevention are trying to popularise the slogan "Don't jack up with a Jock.”

The availability of syringes lies at the heart 
of this problem. In 1981-2 in Edinburgh a surgical supply store and pharmacists who had previously supplied syringes stopped doing so. There were reports of police discouraging the sale of syringes and seizing those found in the possession of drug users. The McClelland committee (1986) reported that, "The resultant non-availability of sterile injecting equipment in the city appears to have contributed to extensive sharing of equipment." Research suggests that most of Edinburgh's HIV positive patients became infected soon after, in 1983-4.

The committee also recommended syringe exchange schemes, which were slow to get off the ground. When they did problems arose which still haven't been resolved. Of Scotland's three exchange clinics, Edinburgh's opens for the shortest time of any in Britain (two hours one afternoon a week), Glasgow's was the only one to attract a local picket, and Dundee's has already closed.

Until recently doctors and pharmacists were deterred from supplying syringes by fears that they could be prosecuted under Scottish common law for "reckless conduct." According to Druglink (November/December 1988), Scotland's Lord Advocate has now made it known that while there can be no general immunity, doctors and pharmacists would be prosecuted only in "exceptional" circumstances and would be safe if they adhered to official guidelines. Circulars issued by the Scottish Home and Health Department recently have been more encouraging.

Critics say that it has taken the statutory bodies too long to recognise that the pattern of AIDS in Scotland differs greatly from that in England, where the authorities have habitually looked for a lead. When the realisation came that drug abusers would have to be targeted hardly any base of specialist drug services was found on which to build. Scotland has no tradition of offering services to this group and when the government's Advisory Council on the Misuse of Drugs recommended that psychiatric input into the management of drug misuse was needed urgently Scotland found itself starting virtually from scratch.

Now that the problems of syringes and needle availability are finally being addressed other problems have surfaced. Several people are now known to have seroconverted through sexual intercourse with drug abusers. That figure is almost certain to increase: in Glasgow 26 of 35 seropositive women are known to be prostituting or to have prostituted in the recent past. Three quarters of 55 prostitutes admitted to injecting drugs (ANSWER, 19 November 1988).

Arguments based solely on the prevalence of HIV have so far won few battles with the Scottish authorities, whose response to the problem of AIDS has been widely regarded in Scotland as slow and unimaginative. With the infected cohort of '83-4 developing AIDS in the next few years and swamping the acute services this may change.

- The BMA is holding a conference, "Caring for AIDS and preventing its spread," in Glasgow, 27-29 January. Details from Alyson Mitchell, BMA Scottish House, 3 Hill Place, Edinburgh EH8 9EQ, 031662 4820. - TONY DELAMOTHE.
Cases of AIDS in the United Kingdom by patient characteristics (cumulative totals up to end of December 1988)

Homosexual or bisexual

Intravenous drug abuser

Homosexual and drug abuser

Haemophiliac

Recipient of blood:

Abroad

UK

$\begin{array}{cccc}\begin{array}{c}\text { Men } \\ (\mathbf{n}=1916)\end{array} & \begin{array}{c}\text { Women } \\ (\mathbf{n}=\mathbf{6 6})\end{array} & \begin{array}{c}\text { Total } \\ (\mathbf{n}=\mathbf{1 9 8 2})\end{array} & \begin{array}{c}\text { Deaths } \\ (\mathbf{n}=1059)\end{array} \\ 1634 & & 1634 & 863 \\ 28 & 11 & 39 & 21 \\ 31 & & 31 & 15 \\ 126 & 1 & 127 & 81 \\ & & & \\ 10 & 10 & 20 & 13 \\ 10 & 5 & 15 & 12 \\ & & & \\ 5 & 10 & 15 & 5 \\ 38 & 16 & 54 & 22 \\ & & & \\ 5 & 2 & 7 & 5 \\ 9 & 10 & 19 & 8 \\ 20 & 1 & 21 & 14\end{array}$

Heterosexual:

Partner(s) with above risk factors Others ${ }^{\star}$ :

With known exposure abroad $\dagger$

With no evidence of exposure abroad

Child of at risk or infected parent

Other or undetermined

20

*Not known to have above risk factor(s).

†Includes people without other identified risks from countries where heterosexual transmission is common.

Prepared from direct voluntary confidential reports by clinicians to the PHLS Communicable Diseases Surveillance Centre $(01200$ 6868) and the Communicable Diseases (Scotland) Unit (041 9467120 ).

\section{Education on AIDS at a critical point}

The initial impact of AIDS education had begun to wear off and it was now at a critical point, Mr David Mellor, Minister of State for Health, said in a Commons debate on 13 January. He said that apathy must not rule and familiarity must not breed indifference. Preventing the spread of the disease depended crucially on people who were at risk changing their behaviour.

But Mr Mellor said that, though homosexuals seemed to have responded, there was no great evidence that intravenous dri:g users were heeding the warnings, and they were the bridgehead into the wider community.

The minister confirmed that almost $£ 130 \mathrm{~m}$ would be spent on AIDS in England in 1989-90 and announced the issue of a circular to local authorities about their share of $£ 7 \mathrm{~m}$ for AIDS related social services expenditure. He said that genitourinary clinics would be raised from their previous Cinderella role to play a vital part against the disease.

We were, he said, no nearer a cure or a vaccine and it was worrying that estimates of the number of patients who were HIV positive who would go on to develop AIDS had risen. Five years ago there was thought to be a one in 10 chance of HIV infection progressing to AIDS, but it was now thought that the risk was over $80 \%$. Mr Mellor said that the United Kingdom had passed the sombre milestone of 1000 deaths and this month the number of reported cases would pass 2000.

For Labour, Miss Harriet Harman said that the government was not spending enough on the problem. Preventive and community services were inadequate, and she feared a drift towards the position in the United States, where AIDS sufferers were dying on the streets. - JOHN WARDEN

\section{Leonardo da Vinci exhibition}

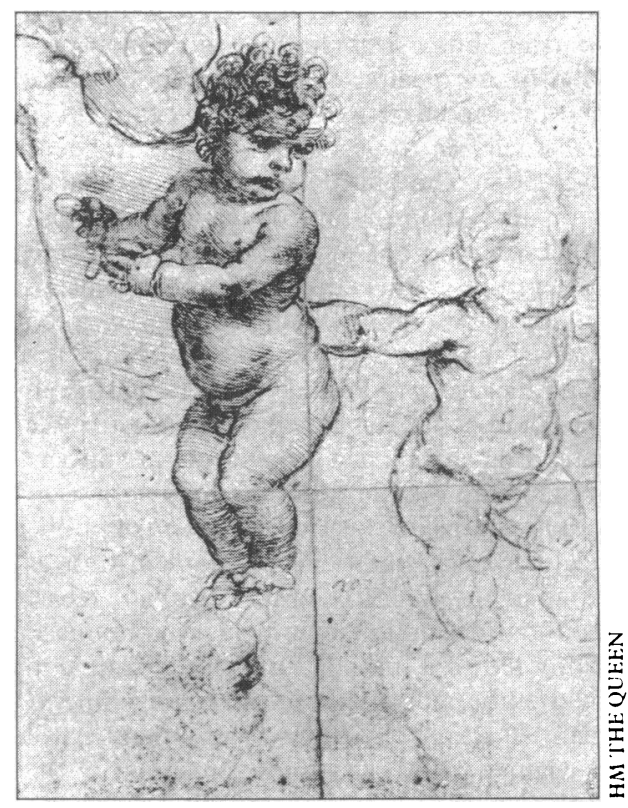

An exhibition of the work of Leonardo da Vinci, artist, inventor, scientist, and engineer, opens this month at London's Hayward Gallery. 
The exhibition includes drawings from many public and private collections: 88 works have been lent by Her Majesty the Queen. Other attractions include an $11 \mathrm{~m}$ model of a flying machine based on Leonardo's drawings, computer graphic sequences, and 14 large scale models that show his interest in mechanics and engineering. A selection of anatomical drawings will also be on show.

Leonardo lived during a time of great intellectual awakening. Many universities had been established in the thirteenth and fourteenth centuries and most had developed medical faculties. Anatomical texts were available as Latin translations of Arabic writers and of the works of Galen, and the practice of anatomical dissection had lost its repugnance. Leonardo is thought to have dissected some 30 bodies, but unlike most of the artists of his day, who used anatomy only as a means to an end, he seems to have studied it for its own sake. - SUE HEELS

Leonardo da Vinci runs at the Hayward Gallery, South Bank Centre, London, from 26 January until 16 April.

\section{University teachers' action could hit medical exams}

On 9 January university teachers started industrial action by refusing to cooperate in examining students. This action could affect the examinations of medical students and if prolonged could possibly delay the graduation of some medical students and thus affect the appointment of preregistration house officers in the NHS.

Recommended by the Association of University Teachers (AUT) after a ballot, the action was taken because the universities have refused to offer academic staff a pay rise for 1988-9. In March 1988 academic staff received a $6 \%$ increase that was the final tranche of a catching up award announced in 1986. But the Committee of Vice Chancellors and Principals (CVCP) claims that the universities have no money to give any other increase this year.

In a letter to the BMA John Akker, deputy general secretary of the AUT, said that the CVCP has "refused to negotiate a pay increase for the academic and academic related staff for 1988-9 and 1989-90." He called on the BMA to ask its members in universities not to "take any action which could undermine [the] impact [of non-cooperation in examinations] in the universities."

Nearly $65 \%$ of medical academic staff belong to the BMA, including some doctors in preclinical departments, where the action could bite first in the spring preclinical examinations. The BMA negotiates for clinical staff, but its attempts to negotiate for doctors working in preclinical departments have been regularly rebuffed by the AUT and the universities.

At its meeting on 13 January the BMA's Medical Academic Staff Committee sympathised with the problems faced by its colleagues in preclinical departments. The committee also issued a statement making clear that though it supported medically qualified AUT members it was for individual doctors to decide what form the support should take. The statement also called on BMA members to take every opportunity to publicise the cause of their non-clinical colleagues, suggesting that it was for individuals to decide on the level and extent to which they would actively support AUT action.GORDON MACPHERSON

\section{New technique for repairing facial defects}

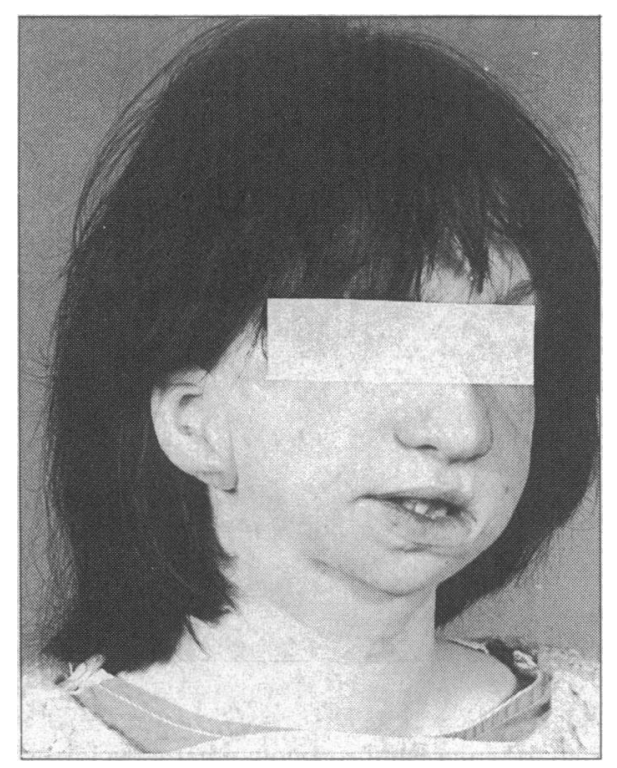

Patient with a prosthetic ear fixed with the new osseointegrated technique. (Reproduced by permission of $\mathrm{Mr}$ $R D$ Manderson)

The Eastman Dental Hospital in London is conducting a study, funded by the Department of Health, of a new treatment for patients with extensive facial defects.

Increased skills in diagnosis, surgical techniques, and anaesthetic care mean improved survival rates for patients with orofacial cancer, but after surgery many have defects requiring large prostheses. Some congenital defects, such as absence or malformation of the external ear, also need large prostheses. Sometimes the prosthesis can be stabilised by attaching it to the teeth, but often it must be secured to soft tissuesby locking appliances below natural changes in contour, fixing them to spectacle frames, or using adhesives - and inevitably the appliances move easily.

In Sweden a dental implant system has been developed for stabilising bridges and other prostheses. The titanium implants are fixed in intimate contact with the jawbone, where they become "osseointegrated." Recently, the technique has been extended to fix external prostheses, particularly ears and osteoconductive hearing aids.

The Eastman Dental Hospital will use the new system to treat extraoral and intraoral defects. The work is intricate and requires skilled surgical, prosthodontic, nursing, and technical teams. Patients are carefully selected - they must have no systemic illness that might prejudice the success of the implant and have adequate amounts of good quality bone to house the implant and suitable overlying soft tissue to cover it.

A temporary prosthesis is used to assess the effects of the final device and to decide on the best way of fixing it. The implants are inserted in a two stage procedure separated by three to six months. In the first stage the bone is exposed and prepared and the fixtures are placed into tapped holes. They are left buried, while they become integrated with the bone. At the second operation the implants are exposed and the superstructures are added. The prosthesis is then mounted on these and effectively becomes fixed to the underlying skeleton.

Osseointegrated dental implants have a success rate of $85-95 \%$ over 15 ycars, and early results for the new application are encouraging. - J A HOBKIRK, Eastman Dental Hospital, London WC1X $8 L D$

\section{No fault compensation}

Members of the BMA's working party on no fault compensation must have been surprised at the reception their proposals received at last week's joint BMA-Royal Society of Medicine conference on the subject. Their ideas, outlined by chairman David Bolt, were given a qualified welcome by lawyers but panned by patients' representatives.

The BMA scheme would exclude injuries arising from reasonable diagnostic error or unavoidable complications of any procedure competently performed. Pain and suffering would be compensated, but psychological damage would not. Injury from infection introduced during a procedure would be compensated, but exclusions would apply to operations concerning already infected organs or tissues, tissues of diminished vitality, prolonged catheterisation or drainage, prostheses in situ for a year or more, and patients with defective immune resistance.

Injury resulting from drugs used in accordance with the manufacturer's instructions would be excluded but could be covered under a separate scheme, as occurs in Sweden. Patients would retain a right to sue in the courts. Pain and suffering and injuries such as facial scarring, sterility, or damage to an organ leaving capacity to work or expectation of life unaffected would be compensated by a lump sum. Financial loss or expense would be dealt with by payments at intervals, probably with a ceiling of, for instance, twice the national average wage.

$\mathrm{Mr}$ Bolt criticised the government for its firm stance against no fault compensation. The Department of Health's official line is that any changes must await an assessment of improvements in the legal system, expected to be outlined later this month in a white 
paper on the civil justice review and introduced in a bill in the autumn.

The BMA's proposals were attacked by Arnold Simanowitz, founder and director of Action for the Victims of Medical Accidents. They ignored the issue of doctors' accountability, which for most victims was more important than compensation, he said. The legal system provided a window on the world of medical accidents which otherwise the public would not see. Without a change of attitude among doctors no fault compensation should not be handed over lock, stock, and barrel to the medical profession, which had in the past let victims down so badly.

Mr Simanowitz cited one of his organisation's cases, concerning a man who suffered severe damage to his eyesight in an intensive care unit after an operation for replacement of a mitral valve. Two independent consultants, a neurosurgeon and a neurologist, both advised that there was no negligence. The health authority told the man's wife that her husband had suffered a temporary stroke, which happened to $10 \%$ of patients undergoing open heart operations. Action for the Victims of Medical Accidents passed the papers to a consultant anaesthetist experienced in intensive care, who found that hypoxia had been caused by premature removal of an endotracheal tube and termination of ventilation, which he said was grossly negligent. The case was settled out of court for $£ 45000$, but $\mathrm{Mr}$ Simanowitz said that the man would not have received a penny under the no fault schemes in Sweden or New Zealand, or any other scheme now proposed. "How many of the $10 \%$ of these accidents even now will continue to be seen as 'known risk' accidents?" he asked.

The two solicitors speaking, who were on opposite sides in the benoxaprofen litigation - Mark Mildred, who acts for plaintiffs, and David McIntosh, who represents defendants-agreed that if a fair and practical no fault scheme could be devised for medical accident victims they would welcome it. $\mathrm{Mr}$ Mildred was concerned that only $50 \%$ of claims were accepted under the Swedish scheme. Change was certainly needed, but much could be done through the procedural changes about to be implemented, he argued. $\mathrm{Mr}$ McIntosh, who acted for Eli Lilly in the benoxaprofen cases, criticised doctors' advisers for "nearly always defending to the hilt" medical negligence claims, and questioned whether the adverse publicity generated made the savings worth while. $\mathrm{He}$ supported a pilot no fault scheme for medical and drug related accidents to run in tandem with the tort system.-CLARE DYER, legal correspondent

\section{Conflict over cyclotron}

Those readers who are following the debate over the government's decision to give $£ 6 \mathrm{~m}$ towards a cyclotron to be sited at St Thomas's Hospital in London (24-31 December, p 625)

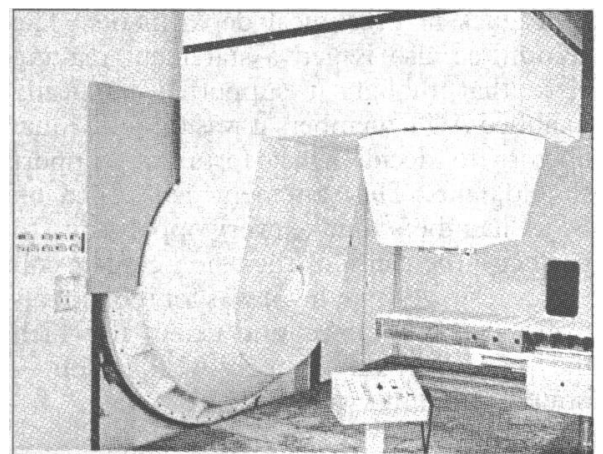

the government's decision ( $p$ 113). Her case is attacked this week by radiotherapists from London and Edinburgh (p 183), and two plastic surgeons from London describe the serious side effects of neutron treatment that they have seen ( $p$ 183).

\section{Gesundheitsreform: reforming German health care}

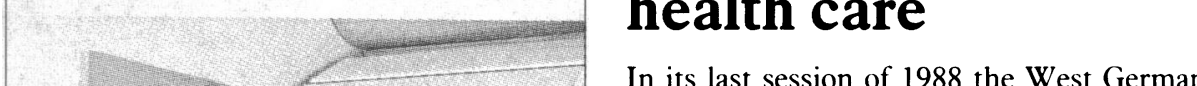
parliament passed the GesundheitsreformGesetz or Health Reform Act. The new legislation had become overdue because yearly health insurance expenditure in West Germany had soared from DM 74 billion ( $£ 24$ billion) in 1978 to DM 124 billion ( $£ 41$ billion) in 1987 and the deficit of the public health insurance system had grown to DM 1.3 billion $(£ 430 \mathrm{~m})$ a year.

In the Federal Republic of Germany enrolment in the public health insurance system is mandatory by law for all employees in the low and middle income groups and for freelance professionals such as artists, writers, and journalists. In the case of employees the employer contributes half of the yearly health insurance premiums, and in the case of freelancers the federal government does. Employees with incomes higher than DM 4575 (£1525) a month are allowed to choose between the public insurance system and private health insurance schemes but will still obtain an employer's share of up to half of their health insurance premiums.

The new legislation became effective on 1 January, more than two vears after Norbert Blüm, West German minister of social affairs, described the first outlines of the coming bill.

The greatest impact of the new regulations

may be interested to know what a cyclotron looks like. The one in the picture comes from Seattle in the United States but closely resembles the machine currently in use at Clatterbridge on Merseyside.

The machine produces high energy neutrons and photons and is being used in Clatterbridge to treat many types of cancer that are reputed to be radioresistant. The machine was opened in 1984 and resulted from unprecedented collaboration: the Imperial Cancer Research Fund, the Clatterbridge Cancer Research Trust, and the Cancer and Polio Research Fund paid for the machine, which was built in Sweden; the Cancer Research Campaign endowed a chair of radiation oncology in Liverpool; the Medical Research Council paid for staff and operating costs; and various groups paid for other parts of the programme. Definitive results are not yet available from Clatterbridge, and critics of the decision to fund the machine at St Thomas's say that the government should wait until they are available.

Representatives of the United Kingdom coordinating committee on cancer research went last week to see David Mellor, Minister of Health, to ask him to reconsider the government's decision. Meanwhile, the debate continues in the $B M F$ and in other places. $\mathrm{Dr}$ Mary Catterall, the pioneer of neutron treatment in Britain, wrote last week defending may be on drug prescribing. Doctors in Germany have for a long time been assumed to be aware of costs in prescribing drugs and to select the least expensive one available whenever there is a choice between equivalent drugs at different prices. But the public insurance scheme could curb doctors only if their prescribing habits continued to be excessively costly. Under the reform act patients will have to pay the difference in price if they or their doctors insist on a more expensive drug without a plausible reason.

Patients from now on will also have to pay a so called prescription fee of DM $3(£ 1)$ instead of DM $2(67 p)$ for each prescription, and from 1992 they will have to pay $15 \%$ of the cost of the prescription up to a maximum of DM 15 (£5). A hospital fee of DM 5 (£1.70) a day was doubled to DM $10(£ 3.40)$ a day, with a maximum of 14 days a year. The unemployed and those who earn very low incomes are exempt. Insurance compensation for prosthetic materials and work was cut most from about $77 \%$ to $60 \%$ on average, so that patients pay $40 \%$. The costs of treatment, however, will be fully compensated as before.

Other restrictions affect the compensation rates for new spectacles, massage treatments, 
the costs of transportation to and from doctors and hospitals, home patient care, spa cures, the costs of treatment in countries outside the European Community, and even funeral expenses. The improvements offered are new screening programmes for caries for those aged 12-20 years and for diabetes and coronary and kidney diseases for those over 35. The public insurance system will be urged to refund premiums to those who have not used the services during the past few years. Criticism about the act particularly concentrated on Blüm's decision to drop a so called "solidarity contribution" of DM 1.4 billion $(£ 470 \mathrm{~m})$ a year from the pharmaceutical industry, which was initially in the bill. Doubts are now arising about whether the act will save DM $13.5 \mathrm{~m}(£ 4.5 \mathrm{~m})$ in health costs a year, as envisaged by Blüm. Speakers of the government coalition in Bonn never- theless called the Gesundheitsreform an "urgent readjustment," whereas the political opposition, which objected to the law from the beginning, called it "unsocial" and a "meanness to the public." Controversy, in any case, was sufficient for the Gesellschaft für deutsche Sprache (German Language Society) late in December to elect Gesundheitsreform the word of the year for 1988. HELMUT L KARCHER, Munich

\section{Letter from Westminster}

\section{Government wants pay flexibility in Whitley councils}

In terms of manpower the NHS is customarily ranked second only to the Red Army, though if Mikhail Gorbachev is to be believed the latter is shrinking while under Mrs Thatcher the former is growing. In the latest return the workforce of the NHS in 1987 comprised 975000 directly employed staff.

Divided also in the manner of the Red Army, the service is made up of 579000 front line doctors, dentists, and nurses; 1550 staff officers in the shape of general managers; and some 390000 support troops of scientists, technicians, and catering and clerical staff. More by accident than intent, these three cohorts also have their own distinctive pay machinery.

Doctors, dentists, and nurses exult in pay review bodies reporting to the Prime Minister. Their accelerated reports for the 1989 review should now be on her desk. Managers have their pay fixed directly by the Secretary of State for Health. The remaining staff-the support troops-are mostly locked into the original negotiating system of Whitley councils.

Last week Mr Frank Field's social services select committee began a three week exploration into the byzantine world of the Whitley councils, which have existed since 1948. As part of its inquiry into resources for the NHS the committee is wise not to overlook the so called "negotiated groups." After all, for there to be more consultants implies also more biochemists and medical secretaries, whose pay and conditions : of service are under the umbrella of the Whitley council system.

One anxiety among MPs is a widening gap perceived in the relative pay of the Whitley groups and those who are covered by review bodies. A glaring example would be last year's $19 \%$ average pay rise for nurses and $5 \%$ awarded by the administrative and clerical staffs Whitley council. But such comparisons can mislead. Pay levels at the bottom of the nurses' award are not greatly different from those in the negotiated settlements.

There is no hiding the increasing strain to find skills like those of medical physicists or clinical psychologists and to compete with the high street pharmacies. More managers are resorting to the practice of "grade drift," which means advertising for higher grades than are needed to fill vacancies as a way of increasing pay.

The Department of Health now proposes to meet the problem by introducing local pay flexibility for all Whitley council grades. National negotiations will proceed, but managements will be able to respond to local markets by adding pay supplements or adapting conditions of service for particular groups. The proposal has still to grind through the Whitley machinery.

It follows a similar plan for nurses, put up last year by the department to the review body, whose verdict is awaited. More light can be shed on what is proposed. A $£ 5 \mathrm{~m}$ pilot scheme in the nurse starved south of England will allow three options by way of pay supplements $-2 \frac{1}{2} \%$ to $5 \%, £ 250$ to $£ 500$ in cash, and one or two points up the pay scale.

As the aim is to entice new entrants to nursing steps will be taken to avoid managers poaching each other's staff. Regions will be given a vetting role. If the regional assessment is that nurses will simply be moved from one area to another pay variation will not proceed.

The witnesses from the management side left an impression with the select committee that the Whitley councils are up to the job.

\section{CMO does his duty}

No such confidence about the authorities having a grip on the problem of salmonella in eggs could be gained from the opening hearing, on the same day, of the agriculture select committee's inquiry. It neither proved nor disproved Mrs Edwina Currie's assertion that most egg production is infected. But more disturbing was the impression of two Whitehall departments, health and agriculture, agreeing to differ rather than to act in concert. There is so far little closing of the divide between the public health and the veterinary compartments. As a result they served up a curate's egg of evidence to the effect that while the risk to humans was serious it was minimal in poultry and eggs. A more impartial committee would not have swallowed it.

But health professionals should certainly respect the unequivocal warning from their colleague Sir Donald Acheson, the chief medical officer, along with Dr J W G Smith, director of the Public Health Laboratory Service. Far from being deflected by political and commercial vested interests they stood their ground.

Sir Donald judged that salmonella in

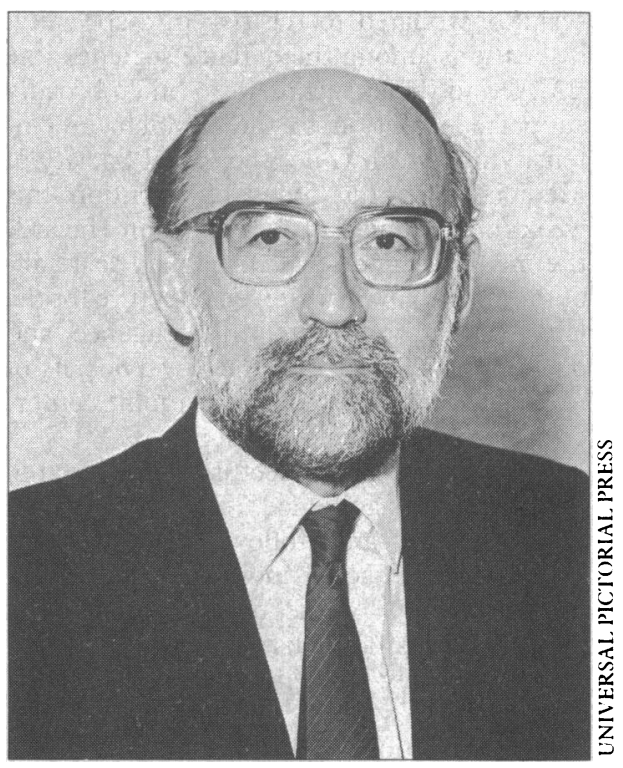

The chief medical officer, Sir Donald Acheson, stood his ground on the problem of salmonella in eggs

eggs was probably responsible for several thousand cases of illness last year and that it was now a serious cause of food poisoning in Britain. He did not put it in the same category as other preventable illnesses such as coronaries and cancer, though he said that it was far from trivial and unless controlled would continue to cause many outbreaks and sporadic cases of illness. Dr Smith's estimates suggest that some 6000 cases of food poisoning from eggs infected with Salmonella enteritidis occurred in the first 10 months of 1988 and that England and Wales were experiencing an epidemic.

With 200 million eggs consumed each week, Sir Donald was adamant that even if the proportion infected was very low it could still cause a substantial amount of illness in the population at large. "I have no doubt at all that there is a serious public health problem associated with the occurrence of Salmonella enteritidis in eggs in this country," he said. He hoped that his health warnings might have some effect but admitted difficulties in determining what was a sufficiently cooked egg (seven minutes is now advised). The key factor in his view would be the control of infection at source.

Egg producers and their allies in the Ministry of Agriculture take refuge in the 
elusive nature of the organism and the consequent lack of absolute proof at source. A mere 31 isolations were reported in chicken flocks. But $13 \%$ of poultry feed sampled at production plants showed contamination.
And while this figure has fallen from $31 \cdot 7 \%$ since 1982 , there is no check on what further contamination occurs on the farm.

The chief medical officer has done his duty, not the least of which was to alert other doctors to take account of a possibly unsuspected risk to public health. The facts are more likely to emerge from their vigilance than from any select committee's report.JOHN WARDEN

\section{The Week}

\section{BMA secretary wants independent inquiry into negligence}

The medicopolitical flavour of the week has been medical indemnity. With 1 April approaching, when the Medical Protection Society intends to introduce differential subscriptions related to the risk of a specialty, discussions among the defence societies, the BMA, and the government to find a broadly supported solution to the problem are intensifying. Meanwhile, the Royal Society of Medicine was the focus of attention this week: on Wednesday evening John Havard, the medically and legally qualified secretary of the BMA, gave the Stevens "lecture for the laity," speaking on medical negligence, and on Thursday and Friday the Royal Society of Medicine and the BMA held a joint conference on no fault compensation.

The Stevens annual lecture is delivered to a "black tie" audience. The fact that it was preceded and followed by excellent hospitality detracted not one whit from the seriousness of the occasion, and John Havard's large and distinguished audience heard a closely argued case criticising the existing tort system for settling medical negligence actions and calling for a comprehensive independent inquiry into what he labelled the "mounting dilemma." Anyone familiar with Dr Havard's views on the subject knows that he has long been opposed to the adversarial system for establishing cause and liability in medical negligence cases. He has certainly convinced me, and surprisingly his forcefully argued case at the Royal Society of Medicine provoked little reaction from the lawyers in the audience during the concluding question and answer session.

Dr Havard's lecture will be published by the society, but let me quote a phrase or two from his comments on expert witnesses.

English law is almost unique in laying down no qualifications for expert witnesses, other than those which can be established by the one side discrediting the qualifications of experts called by the other side. Indeed, the outcome of a case may often depend upon the success with which the one side demolishes the expert evidence produced by the other side. This is in marked contrast to the way in which expert evidence is dealt with under the civil law systems adopted by the majority of countries in the European communities to which we now belong.

The situation called, he warned, for some decisions by both the legal and the medical professions. The legal profession should recognise that the substantive law of tort was beginning to work against the public interest so far as medical negligence was concerned and that the adversarial procedure was wholly unsuited to determining both causation and, even more important, liability in such cases.

\section{Poor communications cause trouble}

The defence societies' annual reports show time and again that poor communications between doctors and patients before treatment and after complaints are the cause of much trouble. Dr Havard emphasised this perennial hazard, going on to remind his audience that patients had enjoyed great benefits from advances in medical and surgical procedures, of which well over seven million a year were carried out in NHS hospitals. The threat posed both to access and to quality of health care by the rapidly changing developments in medical negligence cases was, the BMA secretary argued, clearly disproportionate to the relatively small number of cases in which damage to patients had occurred as a result of the carelessness or incompetence of medical staff.

That places this difficult problem in perspective, but much more negotiation will be needed to resolve it.

The Royal Society of Medicine and BMA meeting is reported at $\mathrm{p} 143$ by Clare Dyer, the BMF's legal correspondent. All I would add is that Mr David Bolt's proposals for a limited no fault compensation scheme were reported to the BMA council at its January meeting and summarised by the $B M \mathcal{F}$ (14 January, p 122).

\section{BMA and government want hours cut}

I ended up last week's column by briefly reporting the outcome of the meeting on 9 January between Kenneth Clarke, Secretary of State for Health, and the BMA on junior doctors' hours of work. The respective sides held separate press conferences after the meeting. These were refreshingly free from polemics, with both the government and the profession acknowledging the gravity and complexity of the problem and seeking constructive ways to resolve it. Kenneth Clarke disagreed with the juniors that legislation was the way out of the impasse. Even so, there was more accord than I expected.

Dr John Marks, chairman of the BMA council, reported a "cordial meeting." Describing the problem as not simple with no simple solution for the whole country, he urged that the important thing was to follow the programme of district working parties set in motion last year and to make sure that it worked. "The key element is to increase the number of consultants, and the government and the profession are committed to that."

Dr Marks called for a commitment by all parties to reduce the workload of juniors, and that had to be done nationally and locally. It was important to get the working parties at local level together and to make sure that they did their job. Mr Mellor, the Minister for Health, had asked for their reports, and he would convene another meeting in a month's time. "All sides must work together, and we are as committed as the government to solving the problem," promised the chairman of council.

Kenneth Clarke declared that the government had been anxious to reduce juniors' hours for some time and had been working with the profession. "Junior doctors," he said, "have always had to work long hours. But it is desirable in modern conditions to get these down for the benefit of patients and doctors. We continue to share a desire to get onerous hours down."

This all suggests that a solution is possible, but to achieve it good will at the top will need to be matched by good will and determined efforts among junior doctors, consultants, and administrators in districts, units, and departments.

In its customarily efficient way the BMA's parliamentary relations unit has produced an excellent brief on junior doctors' hours to help MPs and lords understand the background to Lord Rea's bill to reduce those hours. The brief tells them, for example, that a fifth of all rotas are more onerous than one in three ( 84 hours a week) and that in some districts over two thirds of junior posts include one in two rotas or worse (104 hours a week). The BMA also points out that on any rota a junior may go on duty on Friday morning and come off on Monday evening with little rest between cases.

On the political front we now await the outcome of David Mellor's investigation, which should be available in two or three weeks, when we shall all be reeling from the publication of the Prime Minister's review and possibly the publication of the review body's report on doctors' pay (early this year) and the report of the inquiry into the profession's advertising rules. Finally, just possibly we might even find ourselves short of a house officer or two later this year if the Association of University Teachers' boycott of examinations over its pay dispute is both protracted and effective ( $p$ 143). What a happy new year.

SCRUTATOR 